\title{
Resource consumption in psychiatric intensive care: the cost of aggression
}

\author{
Clive E. Hyde and Colina Harrower-Wilson
}

Tho coets of operating a poychicitic intenstve corse unit (PICU) were recorded for a stx-month pertod. There were 110 admistons and 99 discharges. Misen length of stoy wos 12.3 dars. Totel coets were $\$ 346,516$ over the study pertod, 2203.56 per pettent-doy. Fleed coets compitasd

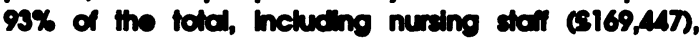
overneads (577,017), medicel stefl (S48,819), hotel costs (S24,160) and miscelloneous $(\$ 1,750)$. Verioblo cotts included speclel nuring, $(S 19,405)$, trectiment of mojor selt-ham $(93,02 A)$, drugs $(\$ 1,707)$ and stefl tim to moncos ogereatvo incidents $(S 1,188)$. Rectuction of the

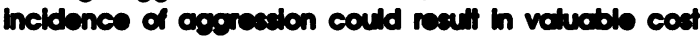
ecovings.

Previous reports have suggested that the level of serious violence in psychiatric patients is low (Pearson et al, 1986). However, there is now concern that the level of violence is increasing (James et al, 1990; Omérov et al, 1990). Violence has obvious undesirable effects (eg. Increased staff and patient stress and a generally poor atmosphere on the ward), and may also be associated with altered staff attitudes towards, and poorer outcomes for, violent patients (Karson et al, 1991). Psychiatric intenstve care units (PICUs) have been set up to provide better care for this small group of highly disturbed patients (Hyde \& Harrower-Wilson, 1994).

It has been estimated that aggression increases the cost of care, with violent schizophrenics costing $43 \%$ more to treat than non-violent schizophrenics (Karson et al, 1991). O'Dwyer \& Mann (1989) described a 15-bed psychiatric intenstve care ward (PICU) with an annual budget of $£ 202,386$, but there is little information published on the breakdown of costs. The prospective study presented here measured the total costs of such a unit for stx months, differentlating between fixed and varlable costs and estimating the additional cost incurred by violent patients.

\section{The study}

The study consisted of a prospective analysis of all patients admitted to the PICU of the Department of Psychiatry at the Withington Hospital, Manchester, between 17 May and 17 November 1993. The Psychiatric studies in Aggression Database (PSAD), previously described (Hyde et al, 1994), was used to record information for each patient, including demographic detalls, diagnosis, nursing and medical staff involvement, drug treatment and detalls of violent incidents (using the Staff Observation Aggression Scale (SOAS) questionnaire (Palmstlerna \& Wistedt, 1985).

Since this was a study of the cost of operating a PICU for six months, only costs relevant to the unit were included. No attempt was made to measure the non-NHS costs of psychiatric violence.

Fixed costs were defined as those costs which were independent of short-term variations in patient care or numbers (e.g. hotel costs, overheads, basic staff costs). Variable costs were those dependent on patient numbers and behaviour (drugs, additional staff costs, treating the consequences of aggression).

Hotel costs (domestic cleaning, catering, portering and linen), miscellaneous costs (equipment, travel, uniforms etc), medical staff costs, and general hospital overheads (management, capital costs of land, buildings and equipment, maintenance, energy, water etc.) were supplied by the Management Accounts Department of Withington Hospital, for the financlal year 1993/4.

Nursing staff employment costs (including basic salary, overtime and enhancement payments, pension contributions, superannuation fees, employers' National Insurance costs, annual holiday, sickness absenteeism and study leave) were taken as a weighted mean across all staff grades, and totalled $\$ 9.29$ per working hour for the financial year $1993 / 4$. 
Table 1. Summary of total costs

\begin{tabular}{|c|c|c|}
\hline Cost component & $\begin{array}{l}\text { Coet in stucty } \\
\text { porlod, } s\end{array}$ & $\%$ fotal cost \\
\hline $\begin{array}{l}\text { Fuxed costs } \\
\text { Basic nursing staff complement (employment costs) } \\
\text { Medical staff } \\
\text { Miscellaneous costs } \\
\text { General hospltal overhead } \\
\text { Hotel costs }\end{array}$ & $\begin{array}{r}169,477 \\
48,819 \\
1.750 \\
77,017 \\
24,160\end{array}$ & $\begin{array}{r}49 \\
14 \\
1 \\
22 \\
7\end{array}$ \\
\hline Total fixed costs & 321,193 & 93 \\
\hline $\begin{array}{l}\text { Variable costs } \\
\text { Psychiatilic drugs } \\
\text { Staff thme to handle violent incldents } \\
\text { Consequences of violent incldent (patient infury) } \\
\text { Specid nursing }\end{array}$ & $\begin{array}{r}1,707 \\
1,188 \\
3,024 \\
19,405\end{array}$ & $\begin{array}{l}0.5 \\
0.3 \\
1 \\
6\end{array}$ \\
\hline Total variable costs & 25,323 & 7 \\
\hline Total costs & 346,516 & 100 \\
\hline $\begin{array}{l}\text { Total cost per patient-day } \\
\text {-"Total cost per bed-day }\end{array}$ & $\begin{array}{l}283.56 \\
156.94\end{array}$ & \\
\hline
\end{tabular}

Drug prices were taken from the British National Formulary, September 1992 edition. The cost of treating one patient who incurred major injuries as a result of an aggressive incident was estimated as the charge which would have been made to an external health authority for an orthopaedic case of similar severity.

\section{Findings}

During the six-month study period, there were 110 admissions representing 83 individuals. The mean age was 35 and $61 \%$ were male. Of the 110 admissions, 54 (49\%) were first admissions to the PICU, 34 (31\%) were second admissions, and $22(20 \%)$ third or greater. Only $8 \%$ were admitted informally. The most frequent diagnosis on admission was schizophrenia (42\%), followed by manic depresstve (mixed/rapid cycling) disorder and personality disorder (12\% each), severe depression (10\%), mania (7\%), substance abuse $(3 \%)$, organic disease $(2 \%)$, neurosis (1\%) and other psychiatric disorders (9\%). Most admissions (65\%) were from general psychiatric wards, and this was also the most frequent destination $(79 \%$ of the 99 patients discharged before the study end). Mean length of stay was 12.3 days. Mean ward occupancy was 6.64 patients.

The costs incurred on the PICU over the study period are shown in Table 1 . Hotel costs consisted of cleaning ( $\$ 13,180$ p.a.), portering $(£ 1,600$ p.a.), linen ( $\$ 175$ per week) and catering ( $\$ 10$ per patient per day). Within the psychiatric drug cost, depot neuroleptics cost $£ 718$ (42\% of drug costs), maintenance oral neuroleptics $£ 572$ (34\%), parenteral neuroleptics and tranquillisers given as-needed for agitation $\$ 366$ (21\%), and treatment of extrapyramidal side-effects $\$ 50$ (3\%).

Continuous or special observation required an extra nurse on the ward, and amounted to 87 staff-days during the study period. Of these, $63(72 \%)$ related to patients with severe depression, even though these patients made up only $10 \%$ of the total.

A total of 170 aggresstve incidents occurred, over half of which were committed by 11 patients. In 101 incidents (59\%) the aggression was directed at staff, resulting in visible infury in eight cases (two requiring medical attention). In 20 incidents, the patient's aggression was self-directed. Four of these resulted in moderate harm (requiring medical treatment), and one in major harm. This latter patient absconded from the PICU and jumped off a bridge, sustaining fractures 
of the femur and clavicle which incurred estimated costs of $\$ 3,024$. The cases of moderate harm and staff injury were relattvely minor and the cost of treating them negligible.

Stxty-five aggressive incidents were sufficiently severe to require rapid tranquillisation (RT). The mean duration of an RT incident was 48 minutes from initial alarm to resolution (range 5-205). Most (70\%) required at least three trained nursing staff. The PICU can provide two nurses from its basic staff complement, and calls in additional staff from other wards if necessary. The staff time costs shown in Table 1 represent only the time of these additional staff.

The drug most commonly used for RT was Acuphase (zuclopenthixol acetate), an intermediate-acting neuroleptic which was used (alone or in combination, mainly with lorazepam) in 39 incidents (60\%). Chlorpromazine, haloperidol or droperidol were used in ten incidents (16\%) alone and a further ten (16\%) in combination with lorazepam.

\section{Comments}

The total cost of running the PICU during the study period was \&346,516, which extrapolates to an annual cost of $\$ 693,032$. The average cost per patient-day was $\$ 283.56$ which, with a mean duration of stay of 12.3 days, gives an average cost per admission of f3,488.

The vast majority of the unit's costs (93\%) were fixed, and the largest component was the basic nursing staff complement (49\% of the total cost), reflecting the high staffing levels necessary in PICU (21.7 whole-time equivalents employed on the unit). Variable costs accounted for only $7 \%$ of the total costs, but are of particular interest to management as they are open to modification.

The largest component of varlable costs (77\%) was special nursing. In the study unit, special nursing was mainly used to manage severely depressed patients at risk of selfharm, rather than aggresstve patients. However, anecdotal evidence from a survey of psychiatric wards in the North-West of England suggests that less spectallsed wards rely on special nursing to manage violent patients (Harrower-Wilson \& Hyde, 1994). The high cost of special nursing, revealed by the present study, indicates that this might substantially increase the cost of managing violent patients on general psychiatric wards.

Total drug expenditure was a small component of cost $(7 \%$ of variable cost and $0.5 \%$ of total cost). As-needed neuroleptics, used for the treatment of aggression, amounted to only $1.5 \%$ of the varlable costs. This might have been expected had the unit chiefly used low-priced generics, but the drug of choice was a branded product (Acuphase).

This study recorded eight assaults resulting in visible injury to others from 110 admissions, a much lower rate than the 28 injurious assaults from 58 admissions reported by Walker \& Seffert (1994) in a PICU in London.

The total medication cost of treating aggresstve incidents was $\$ 366$ (as-needed neuroleptic drugs). Non-medication costs were $f 1,188$ for staff time and $\$ 3,024$ for orthopaedic treatment for a single case of major self-harm. Even using our strict definition (costing only those staff who cannot be supplied from the PICU's normal complement), staff time cost outweighed the medication cost by three to one. The cost of treating the consequences of one serious aggresstve act was almost double the total of the other costs of aggression.

The drug of choice for treating violent incidents in the unit under study was Acuphase (zuclopenthixol acetate), an intermediate-acting neuroleptic for the treatment of acute psychosis. Conventional neuroleptic injections have to be given every four hours, an obvious problem in highly disturbed patients lacking insight into their disease, whereas one injected dose of Acuphase remains effective for up to three days (Baastrup et al, 1993). Acuphase has been associated with an incidence of aggression 53\% lower than conventional neuroleptic drugs (Omérov et al, 1990). Since staff time cost far outweighs drug cost in the management of patient aggression, this reduction in violence when Acuphase is used may be associated with significant cost savings, and a further study is underway to investigate this. Improved management of aggression could also reduce the cost of treating the consequences of violence. In addition to these monetary savings, a reduction in violence would have significant non-financial benefits such as better atmosphere on the ward, better patient care and a reduced level of stress for both staff and patients. 


\section{Achowiledrements}

The authors would like to thank Dr Brian Nellist for invaluable assistance in setting up the computer system, the staff of the PICU of the Department of Psychiatry at the Withington Hospital, Manchester for their help in carrying out the study, and Lundbeck Ltd. for financial support.

\section{References}

BAnstruP, P. C., Alotirors, U. G. et al (1993) A controlled Nordic multicentre study of zuclopenthtrol acetate in oll solution, haloperidol and zuclopenthirol in the treatment of acute peychools. Acta Psychiatrica Scandinavica, 87, 48-58

HARROWER-WILSON, C. \& HYDE, C. E. (1994) Service provision for violent and aggresatve patients in the North-West and Merseysudde regjons: a descriptive report. Abstracts: Annual Meeting. Royal College of Poychiatrists, Cork. July 1994 (copies available).

HYDE, C. E., HARROWER-Whson, C. \& Nmust, B. (1994) The Psychlatric Studies in Agresedon Database. Computers in Psychiatry Group of the Royal College of Poychiatrists, Newsletter, June 1994, 8. 2. (Proceedings of the Winter Meeting of the Royal College of Poychiatrists, Software Workshop, Cafe Royal, 4 February, 1994).

HYDE, C. E. \& HARrower-Whison, C. (1994) Peychiatric intenstve care: princtples and problems. Hospttal Update, 287-295.

James, D. V., Ftnirarag, N. A., Shar, A. K. \& Priest, R. G. (1990) An increase in violence on an acute poychiatric ward: a study of associated factors. Brttish Journal of Psychiatry, 188, 846-855.
Kapson, C. N., MCCLmun, J. L. \& KAstrier, T. M. (1991) Assault increases the cost of care among inpatient veterans with schinophrenia Journal of Nervous and Mental Disease, 179, 702-704.

ODWYm, J. M. \& MNN. B. S. (1989) Peychiatric intenstve care after two years. Psychiatric Bulletin, 18, 421-422.

Ontriov, M., Wstwor, B \& Durunv, U. (1990) Agrresatve incidents and acute poychools, the efiect of Zuclopenthtxol acetate. Regional symposium, World Peychiatric Association, Oslo, Norway, 23-26 August. 1990.

PAlmstigrin, T. \& Wrstikd, B. (1985) SOAS-Staff Observation Aggresaton Scale, a new peychiatric rating scale, measuring severity and frequency of aggresstve behaviour. Ind International Congress on Peychogeriatric Mediclne, Umea, Sweden. 28-30 August, 1985.

Pearson, M. Wryor, E. \& PADI, M. (1986) A study of violent behaviour among in-patients in poychiatric hoopttals. Brttsh Joumal of Psychiatry. 149, 232-235.

WALTiR, Z \& S.miraRr, R. (1994) Violent incidents in a peychiatric intenstve care unit. Brttsh Joumal of Psychiatry, 1e4, 826-829.

*Clive E. Hyde, Consultant Psychiatrist; and Colina Harrower-Wilson, Divisional Manager for Nursing and Quality, Department of Psychiatry, Withington Hospital, Nell Lane, Manchester M20 8LR

-Correspondence 